the nature of the fracture is, whether there is any interposition of muscles or ligaments, whether any blood-vessels lave been torn, and we enn remedy all these things, with the expectation of getting a good result afterward. Three cases under my observation at the present time have demonstrated the value of this method. In each of these cases the anterior tibial artery was cut, there was interposition of the muscular structures, and good results simply would not have been possible, except by the open method. The duration of the cases was from three to six months; the patients progressed well and male a complete recovery.

The man who renders first aid has it in his hands to produce fuvorable or unfuvorable results. It is, therefore, incumbent on such men to use the most rigid asepsis, and be prepared to perform the operation where it is indicated; and this can be done in practically every country house, if we are carefur and appreciate what asepsis means.

De A. F. Jonas, Omaha: In my opinion, all simple fracture, will never be treated by the open method for the reason that the operative technic must be in accordance with perfect aseptic surroundings, with trained assistants and proper appliances. Those who have seen Lane operate speak especially of his aseptic technic, which is absolutely faultless, He does not introduce his finger into the wound at any time nor any instrument that has touched the slin or any thing that is of doubtful asepsis. Therefore, he has ideal results. Those of us who have had to operate much in private louses as well as in hospitals know how inadequate ace the rnenus at our command in the former; if we fail in any part of the aseptic procedure, uniou may be imperfect and conditions are worse than they' would have been if we had treated the case by the non-operative methor.

We have run the entire list of mechanical deviees used to keep the bone fragments in apposition, and have finally come to use, to the exclusion of other applinnces, silver plates witl serews and bronze aluminum wire. Early in my experience I found that silver wire was not strong enough and often the wires broke; the fractures nearly always became displaced. I then resorted to the use of bronze aluminum wire, which has a tensile strength four times that of the silver; while the wire was strong enough a partial displacement, of the fragments often occurred, no matter how the wire was applied. Then I resorted to the steel plates of Lane, and found them useful in the majority of instances, except in the ease of a fractured femur or humerus, in which, if the assistant made all awkward or accidental movement while the plaster anst was applied, the serews wer pulled out, and we were obliged to take ofr the dressing, re-open the wound and re-aljust the splint. Therefore, I now use the silver splint of Siek with four or six holes, which is flexible. It will bend rather than break or pull out and the danger of pulling ont the serews, that hold the plite, is not as grent as in the stiff steel plates used by Lane.

\section{CLINICAL RESULTS OF GASTRO-RNTTEROS-} TOMY FOR NON-MIALIGNANT DISEASES*

JOHN DUDYEY DUNHAM, A.B., M.D.

Professor of Diseases of the Stomnch and Dietetics, Starling-Ohto Medical College

Columbus, olio

'L'here have been very few acculate and thorough reports on the results of gastro-enterostomy for ulcer of the stomach.

Bettman and White ${ }^{1}$ have collected reports of 150 cases with results after the lapse of at least one year. Bamberger ${ }^{2}$ has studied 836 cases in which operation was performed for chronic ulcer of the stomach. The former study shows an immediate mortality of 10 per

* Read in the Section on Practice of Medicine of the American Medical Association, at the Slxty-tirst Annual Sesslon, held at St. Louls, June, 1910.

1. Bettman and White: Med. Rec. Oct. 9, 1909.

2. Bamberger. L.: Dle innere und die chirurgische Bchnndlung fes chronlschen Magengeschwur's und lhre Erfolge, Jullus Springer, Berlin, 1009 cent., the latter, 12.2 per cent. To this must be added a late mortality from complications in Bettman and White's series of 14.6 per cent. and in Bamberger's cases of 5 per cent. (complete late reports lacking in many of Bamberger's series).

We find, then a total mortality of 24.6 per cent. in one series and 17.2 per cent. in the second series. The group of 836 cases showed $\gamma 4$ per cent. cures; 13.4 per cent. unchanged. In the group of 150 cases thele were 60 . per cent. of cures and 30 per cent. of deaths, or no improvement.

The basis of the present report consists of forty-eight cases in which the patients were personally examined before operation; in all but two cases tests of the stomach contents and motility were performed. In fifteen cases examinations of stomach functions were made previous and subsequent to the operation. Forty-six patients were operated on by local surgeons, one by Dr. W. J. Mayo and one in Jausanne, Switzerland.

Fifteen patients have died, twelve within 17 days of the operation; an immediate mortality of 25 per cent.; a total mortality of 31.25 per cent; mortality since 1906 , 10.41 per cent. The predominance of males (twelve males, three f'emales), is significant. The average age is 50.5 year's.

Case 8 was instructive. The patient was a man, aged 45 , alcoholic, with a history of ulcer for five years with frequent severe hematemesis. Operation had been repeatedly refused. An ulcer on the anterior aspect of the stomach adjoining the pylorus was found which ruptured during manipulation. Partial gastrectomy with gastro-enterostomy was done. The patient made an uneventful recovery for fifteen days; then peritonitis developed to which he succumbed in two days. Necropsy revealed a ruptured gangrenous appendix with localized peritonitis. The site of operation was not involved. This case is an argument in favor of appendectomy with every gastro-enterostomy.

The three later deaths were due to carcinoma ventriculi in two instances, one six months, one twenty-one months after operation. In each case the patient had apparently recovered. Possibly these two ulcers had already undergone carcinomatous transformation at the time of operation. The third deatl resulted from recurrent hematemesis, morphinism and asthenia.

of the fifteen fatal cases hyperchlorhydria was present in seven, anacidity in two, normal acidity in four, no determination in two. Evidence of retention of chyme was found in seven cases. Five of the patients who died had been treated medically without success. Eight patients received desultory treatment, no correct diagnosis having been made. Surgical treatment should have been given much earlier in these eight fatal cases, as shown by the advanced degree of stenosis secn at operation. Two patients ( 3 and 11) should not have been operated on as no stenosis was found. Recent histories have been obtained in twenty-nine of the thirty-three patients living.

Table 3 gives the data in fifteen cases in which gastric analyses were male before and at varying periods after operation. The average age at time of operation was 43.2 years. There were nine males and six females. In this group twelve had ulcer of pylorus or duodenum with stenosis; one, ulcer of pylorus without stenosis, (Case 18); anotler had nervous dyspepsia (Case 20) and one atony of the stomach with clilatation.

Seven patients with ulcer and stenosis made perfect recoveries, while three recovered but are obliged to abstain from acid and indigestible foods. 
Another case (18) has improved, but has recurrent hematemesis and morphinism.

In Case 20 gastroplication was performed, leaving the patient with an aggravation of symptoms.

In Case 28 (nervous dyspepsia) the gastro-enterostomy has been followed by greater suffering than before the operation.
Examination after an Ewald test breakfast shows free hydrochloric acidity above 40 in six cases, between 20 aud 40, or normal in two; below 20 in six; absent in one.

Hyperchlorhydria has increased after operation in three cases (Nos. 16, 19, 25). One of these patients (No. 16) has regained motor power and is free from

\section{TABIE 1.--IMMLDIATE MORTAIITY (WITHIN SEVEN'LEEN DAYS) *}

\begin{tabular}{|c|c|c|c|c|}
\hline $\begin{array}{c}\text { Case. } \\
1 .\end{array}$ & $\begin{array}{l}\text { Year. } \\
1903\end{array}$ & $\begin{array}{l}\text { Sex. } \\
\text { AI. }\end{array}$ & $\begin{array}{l}\text { Age. } \\
60\end{array}$ & $\begin{array}{l}\text { Dlagnosls. } \\
\text { Pylorlc ulcer ; arterio- } \\
\text { sclerosis ; previous } \\
\text { medical treatment. }\end{array}$ \\
\hline 2. & 1008 & M. & 50 & $\begin{array}{l}\text { Multiple ulcer of py- } \\
\text { lorus } \text { und duo- } \\
\text { dentim; sllght sten- }\end{array}$ \\
\hline 3. & 1904 & M. & 74 & $\begin{array}{l}\text { Ulcer of lesser curva- } \\
\text { ture near pylorns; } \\
\text { no stenosis. }\end{array}$ \\
\hline 4. & 1904 & $\mathbf{M}$. & 51 & $\begin{array}{l}\text { Iylorle ulcer: sten- } \\
\text { osls previous medl- } \\
\text { cal treatment. }\end{array}$ \\
\hline 6. & 1004 & $\mathbf{M}$ & 63 & $\begin{array}{l}\text { Pyloric ulcer; sten- } \\
\text { osis. }\end{array}$ \\
\hline 6. & 1005 & $\mathbf{M}$ & 30 & Pyloric ulcer ; no sten- \\
\hline 7 . & 1006 & Ir. & 30 & Hour-glass stomach \\
\hline 8. & 1906 & M. & 45 & Perforating pyloric ul- \\
\hline$\vartheta$. & 1006 & M. & 30 & $\begin{array}{l}\text { Duodenal ulcer ; slight } \\
\text { stenos!s. }\end{array}$ \\
\hline 10. & 1908 & M. & 65 & $\begin{array}{l}\text { Pyloric ulcer; old per-- } \\
\text { foration : locallew } \\
\text { abscess ; stenosis. }\end{array}$ \\
\hline 11. & 1900 & F. & 35 & $\begin{array}{l}\text { Hematemesis ; clinical } \\
\text { diaunosis ulcer ; no } \\
\text { visible ulcel or } \\
\text { stenosls. }\end{array}$ \\
\hline 12. & 1910 & $\mathbf{M 1}$. & 61 & $\begin{array}{l}\text { Pylorle ulcer (actire) ; } \\
\text { stenosis. }\end{array}$ \\
\hline
\end{tabular}

(isistrlc Inindings. Tlme

1. Tolal Aclaty. Cause of Death. After Operation.

84 $112 \quad$ Slock. 48 hours

65 85 Shock. 6 hours.

60 Hematemesis. 6 days.

10 lietention. 20

$60 \quad 84$

Jacilic. Retention.

20 Ireteution. 34

Iequention.
No tests.

No tests.

6090 Hematemesis. 48 hours.

Vicious circle.

Viclous circle.
12 days ; 6 hour's operation.

Sliock.

10 days.

12 hours.

Gangrenous ap- 17 days.

pendicitis,
Ierforation and 3 days.

peritonitis
peritonitis.

Shock.

24 hours.

Operation.

Gastro-enterostomy.

Gastro-enterostomy.

Gnstro-enterostomy.

Gastro-enterostomy.

Gastro-enterostomy.

Gastro-enterostomy.

Resettion pylorus ;

Gastro-enterostomy

Resection pylorus ;

Gastro-enterostomy.

Gastro-enterostomy.

Gastro-enterostomy.

Gastro-enterostomy.

- Average age, 50.5 years: immediate mortality, 25 per cent.; males 10 ; females 2.

TABLL: 2.-LA'TE MOR'TALITY *

\begin{tabular}{|c|c|c|c|c|c|c|c|c|c|}
\hline $\begin{array}{l}\text { Case. } \\
13\end{array}$ & $\begin{array}{l}\text { Year. } \\
1901\end{array}$ & $\begin{array}{l}\text { Sex. } \\
\text { M. }\end{array}$ & $\begin{array}{c}\text { Age. } \\
\mathbf{3 0}\end{array}$ & $\begin{array}{l}\text { Dingnosls. } \\
\text { Active pylorle ulcer; }\end{array}$ & $\begin{array}{c}\text { Gils } \\
\text { IIt'l. } \\
0\end{array}$ & $\begin{array}{c}\text { trife Findings. } \\
\text { J'otal Acidity. }\end{array}$ & $\begin{array}{l}\text { Cruse of Death. } \\
\text { liecurreut hematemesis. }\end{array}$ & $\begin{array}{l}\text { Time After Operation. } \\
3 \text { months. }\end{array}$ & $\begin{array}{c}\text { Operation. } \\
\text { Gastro-enterostomy. }\end{array}$ \\
\hline 14 & 1008 & $\mathbf{M}$. & 63. & $\begin{array}{l}\text { stenosls. } \\
\text { a od e na l ulcer ; }\end{array}$ & 70 & & Carcinoma & & Gastro-enterostomy. \\
\hline 15 & 1008 & F. & 34 & $\begin{array}{l}\text { Pyloric ulcer; sten- } \\
\text { osis. }\end{array}$ & 23 & $\begin{array}{l}46 \\
\text { IRetention. }\end{array}$ & ventriculi. & $\begin{array}{l}21 \text { mos. after first } \\
\text { opel'atjon. }\end{array}$ & Gastro-enterostomy. \\
\hline
\end{tabular}

* 'lotal mortality 31.25 per cent.: males 12; fuunles 3 ; moitality since 1000, 10.41 per cent.; seven hyperchlorhydria ; four bydrochlorfc acld normal; two hydrochloric acid absent : two not determined.

\section{TAHLE 4.-1RLSUL'PS IN 12 CASHS, 1 TO 6 YEARS AFlER OPERATION}

\begin{tabular}{|c|c|c|c|}
\hline $\begin{array}{c}\text { Case. } \\
31 .\end{array}$ & $\begin{array}{l}\text { Year. } \\
1908\end{array}$ & $\begin{array}{c}\text { Sex. } \\
\text { M. }\end{array}$ & $\begin{array}{c}\text { Age } \\
28\end{array}$ \\
\hline 32. & 1003 & $\mathbf{M}$. & 45 \\
\hline is. & .1004 & F. & 31 \\
\hline 34. & 1004 & $\mathbf{M}$. & 45 \\
\hline 35. & 1004 & Ir. & 50 \\
\hline 30. & 1005 & F. & 30 \\
\hline 37. & 1905 & IF. & 57 \\
\hline 38. & 1907 & II. & 48 \\
\hline 39. & 1008 & IS. & 24 \\
\hline 40. & 1908 & M. & 60 \\
\hline 41. & 1908 & Ir. & 37 \\
\hline 42. & 1900 & $\mathbf{\Delta 1 .}$ & 58 \\
\hline
\end{tabular}

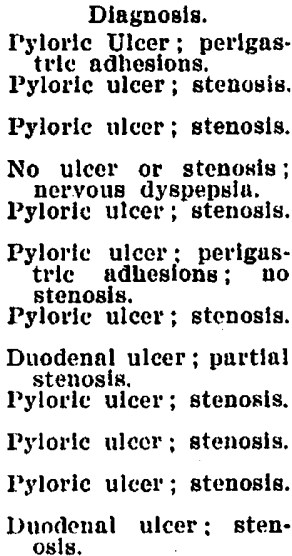

\begin{tabular}{|c|c|}
\hline $\begin{array}{l}\text { Operation. } \\
\text { Gastio-ent. }\end{array}$ & $\begin{array}{l}\text { Result. } \\
\text { I'erfect. }\end{array}$ \\
\hline Gustro-ent. & Improved. \\
\hline $\begin{array}{l}\text { Gastro-eut. } \\
\text { Gastro-eut. }\end{array}$ & $\begin{array}{l}\text { Improved; has byper- } \\
\text { chlorlhydrla. } \\
\text { No fmplo ve m e t } \\
\text { worke. } \\
\text { ltecovery. }\end{array}$ \\
\hline Gastro-ent. & $\begin{array}{l}\text { Made worse: vomit- } \\
\text { lug. }\end{array}$ \\
\hline Gastro-ent. & Perfect. \\
\hline Ginstro-ent. & Perfect. \\
\hline Gastro-ent. & I'erfect. \\
\hline Gastro-ent. & l'erfect. \\
\hline Gastro-ent. & Perfect. \\
\hline Gastro-ent. & Perfect. \\
\hline
\end{tabular}

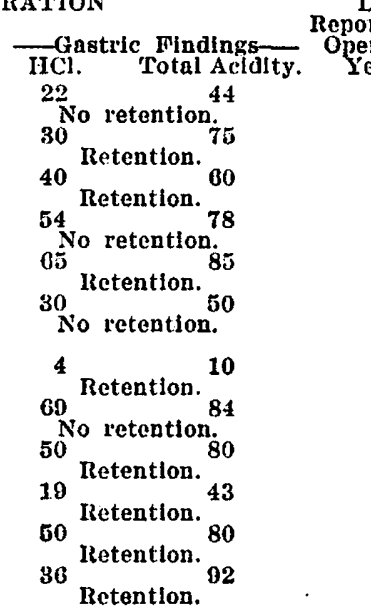

TABLL 5.-SIX CASLS IN WHICH IATE RISUL'SS COULD NOT BE SECURLD

\begin{tabular}{|c|c|c|c|c|}
\hline $\begin{array}{c}\text { Case. } \\
43 .\end{array}$ & $\begin{array}{l}\text { Year. } \\
1005\end{array}$ & $\begin{array}{l}\text { Sex. } \\
\text { F. }\end{array}$ & $\begin{array}{l}\text { Age. } \\
\mathbf{3 5}\end{array}$ & $\begin{array}{l}\text { Diagnosis. } \\
\text { Ulcer lesser curvature }\end{array}$ \\
\hline 44. & 1906 & M. & 40 & Pyjorte ulcer; stenosis. \\
\hline $4 \overline{5}$. & 1907 & I. & 22 & Pylorle ulcer; no sten. \\
\hline 46. & 1907 & M. & 42 & Duodenal ulcer; slight \\
\hline 47. & $19(1 \pi$ & lis. & 30) & $\begin{array}{l}\text { Pylorle ulcer; chole } \\
\text { lithlasis: stenosls. }\end{array}$ \\
\hline 48. & 1909 & li. & 20 & $\begin{array}{l}\text { Pylorle ulcer; no ster } \\
\text { osle. }\end{array}$ \\
\hline
\end{tabular}

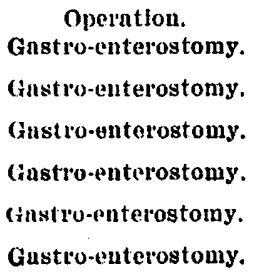

Result. Operatlve Recovery. Operative Recovery. No rellef. Improved. Operative Recovery. Operative Recovery.
Last After

5

5

$\mathbf{3}$

2 

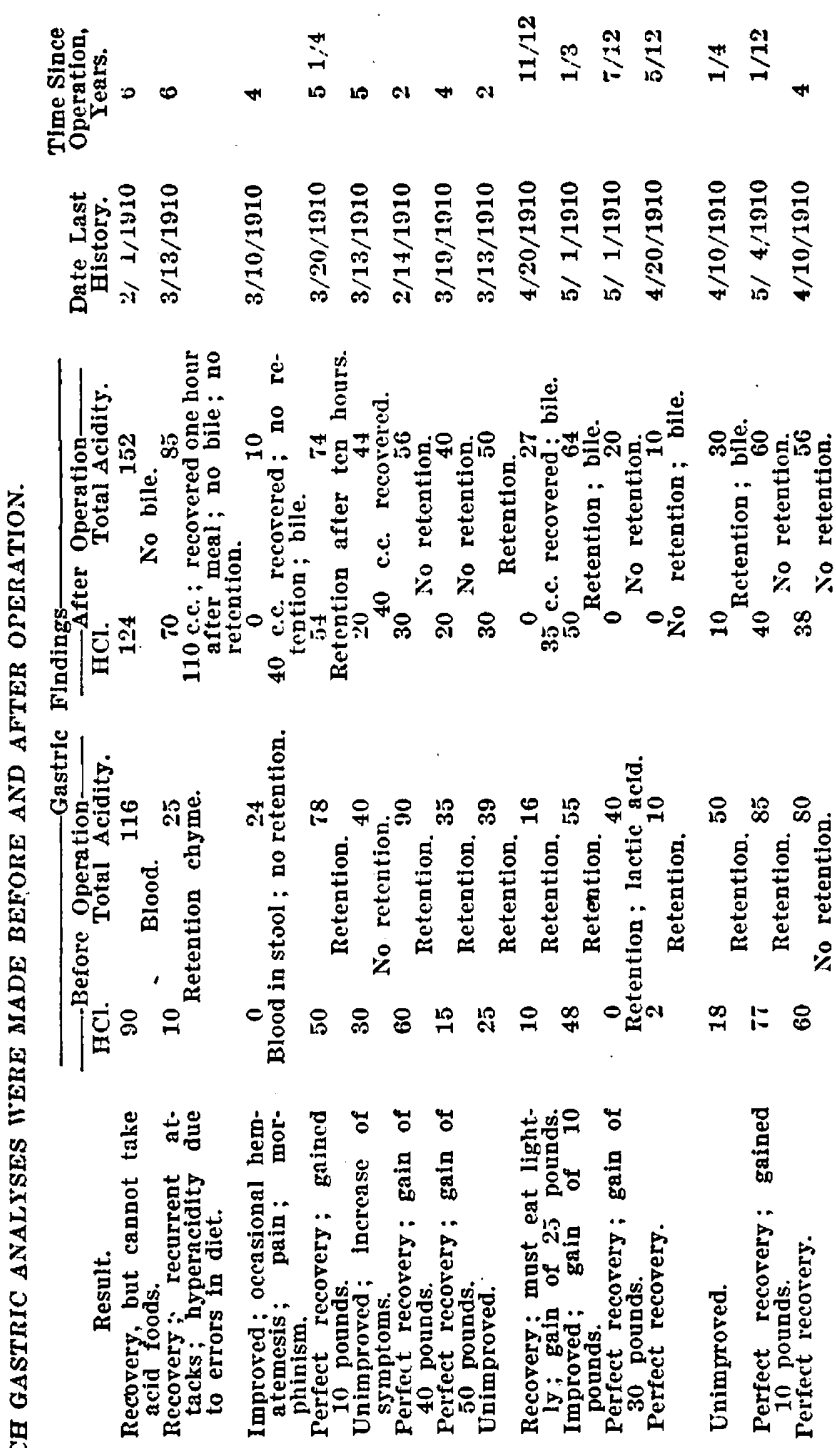

symptoms when he refrains from acid and heavy foods. The second (No. 19) has retention of chyme for ten hours, a greater hyperchlorhydria with a complete recovery from all gastric disturbances.

Hyperchlorhydria has disappeared in three cases (Nos. $21,29,30$ ) and the proper motor function has been restored.

Patient 20, in spite of a clinical history of ulcer with hematemesis, had no visible ulcer scar or stenosis. Five years after operation hydrochloric acidity is within normal limits and motor power is perfect.

Patient 23, who had normal acidity, has two years after operation persistence of motor insufficiency and no improvement in condition. The six patients with hypoacidity have suffered a variety of results. Patient 17 has developed a hyperchlorhydria, has a good motor function and is free from symptoms if he abstains from acid foods.

In Cases 18, 24 and 27 the hypo-acidity has been supplanted by an absence of free hydrochloric acid. In Case 23 the hydrochloric acid has risen to a normal degree and motor power has become established, while in Case 28 the hydrochloric acid has decreased and retention of chyme continues with the patient unimproved. Before operation Patient 26 had an absence of hydrochloric acid with marked retention of chyme. The hydrochloric acid has not reappeared, drainage is now complete within the normal time.

The appearance of bile las usually been noted one hour after the test breakfast, for four months, after which it cannot be detected. Bile was found, however, in Case 18 four years after operation.

Table 4 outlines twelve cases in which results have been ascertained from one to six years after operation. Six cases are included in which operative recoveries only are procurable (Cases 31 to 48 , inclusive). In this group the diagnosis is chronic ulcer of the stomach with stenosis in fourteen; chronic ulcer without stenosis in three; nervous dyspepsia in one.

The following outline shows results in the entire series of 27 patients known to be alive.
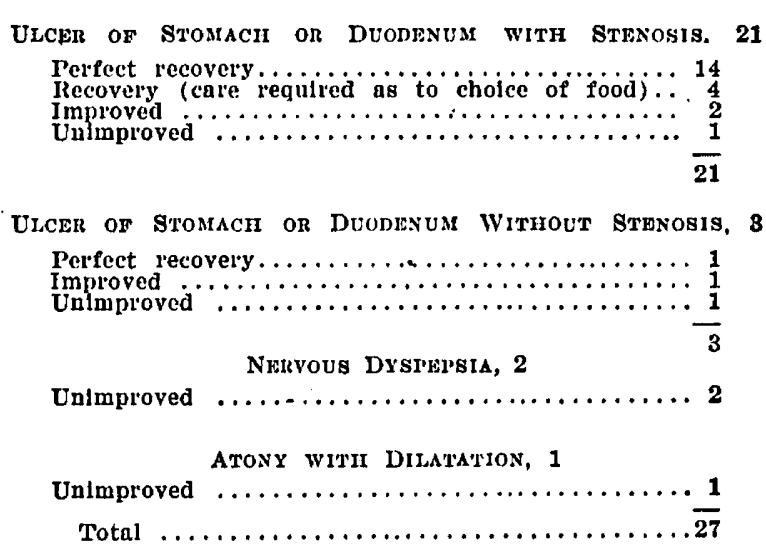

A definition of the term "perfect recovery" as used in this classification depends on unqualifiedly favorable answers to the following questions:

Do you still have trouble with your stomach? Do you have any belching of gas or food? Do you vomit at all? Have you vomited or spit up any blood since the operation? How is your appetite? Do you find it necessary to eat more than turee meals a day? Are your bowels regular or do you find it necessary to take physic for them?

There must also have been the ability to pursue the former vocation or avocation without disturbance. 
The elimination of three cases of nervous dyspepsia, onc of gastric atony and one in which no determination was made enables us to discuss the gastric findings in forty-tliree undoubted cases of ulcer of the prlorus or duodenum.

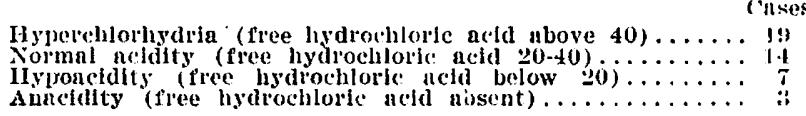

Total $4: 3$

This makes nineseen patients with hyperchlorhydria; twenty-four patients with normal or sulmormal hytrochloric acid.

\section{CONCLISIONS}

1. Hyperehlorhydria as a symptom of chronie gastric ulcer is inconstant and should be disregarded.

2. Perfect recovery may occur when atony of the stomach has existed before the development of ulcer and motor insufficiency persists; illustrated in Case 19.

3. Many of the fatalities cited in this report would have been averted had the family physician made a diagnocis before serious complications had developed. Forty patients in this series of cases gave a history of ulcer covering five years or more before the diagnosis was made.

1. Pylorectomy offered a better prognosis for recovery in five of the fatal cases. Patients 4, 12 and 13 were lost by fatal hemorrhages from the ulcer area. Patients 14 and 15 died as a result of carcinomatous transformation of the pyloric ulcer.

5. 'The legitimate field for gastro-enterostomy in lienion diseases of the stomach is in chronic ulcer near or below the pylorus with stenosis.

The MrLene.

\section{ABSTRACT OF DISCUSSION}

Dr. Judson Daisind, Philadelphia: (hronic gastric nlenr of conserned, although the ulcer itself is still present. The patient scems to recover symptomntically. It is believed that no ulesr is present at all and the case is often pronounced cured. I reall one case in which the funicular uleer was discorered an: removed; this was followed by complete recovery. 'Thi cases of gastric uleer referred to at another session of the Sertion in which the carcinoma was supposed to be cured three times belong to this same group. We see cases of elronic indolent ulcer in which under treatment great improvasuent results and the patients are supposed to be well.

Dr. Milrox J. LicuTr, Cleveland, Ohio: The study of thene? cases and the study of the statisties ought to be of great vilue and help to physicians. I should like to remind the members of the Section of the discussion of this subject three years ano by Dr. Paterson of London, when he spoke of the value of gastroenterostomy in comnection with cases of gastric uleor. He reminded us of the temporary benetit to be derived from gastroenterostomy when there wis incomplete stenosis of the pylorus. I have watched cases since and must say that the West results of the gastroenterostomy were seen in easu's in which the stenosis was almost absolutely complete. One dor's not really know just what to do with cases of incomplete stemosis of the pylorus. Of course, we cannot dictute to the surgeon just what shall be done at the time of operation, but it seems to me that in some cases in which a gastroenteros. tomy has been done, the patient's subsequent condition shows that it would have been better to have done a pylorectomy. It seems also that a pylorectomy should be the operation of choies: whenever possible, and that a gastroenterostomy should only be done when there is complete stenosis of the pylorus.

Dr. Joh A. Wirubrsipon, Nashville, Tenn.: A few yeurs ago a very prominent surgeon regarded this clisease ts a surgieal one. The pendulum has swung back now, and every advanced surgeon is doubting the propriety of operating on gastric uleer unless there are definite evidences of olstruction. I do not feel that gastric uleer belongs to the surgeon for two reasons. Operation in my experience in the past hus been unsuccessful. The patients I have had have recovered immediately, but later they had more or less tronble. Some of the bad ulcers become latent. It is extremely difficult in some cases to determine whether or not the gastric ulcer is cured; we kinow that often by medical treatment alone we may reline patients symptomatically and they may get along well for months, gaining flesls. Yet the condition may remain dorminnt for some time only to awaken into activity again. A few years ago every ease of hemorrhage from the stomach in cases of uleer was referred to the surgeon for trentment; recently it has been found that medical treatment is better in such enses. The surgeon will not intervene now unless there is complete obstruction; then surgery may save many lives which otherwise would be sacrificed.

Dr. Delan cex Rochester, Buffalo, N. Y.: If there is impending obstruction, or actual obstruction, of course immediate operation is indicated. However, a gastroenterostomy is an operation that I believe sloould be avoided wherever possible. If any operation is to be done at all I should say that the one to be preferred was pylorectomy. I agree with Dr. Witherspoon that much can be done by medical and dietetic treatment in these ases and an operation should not be urged on patients with gastric ulcer unless it is absolutely necessary, because of the danger of cancer developing. This is a possibility, although a possibility only. Such good results are obtained from medical and dietetic treatment if contimed for a sufficient length of time that operative meas. ures should be avoided if possible.

DR. A. J. Brenevict, Buffalo, N. Y.: My experience with gastroenterostomy for either malignant or non-malignant disease of the pylorus is limited to one or two cases, because such an operation secmed inadvisable. In cases in which there is marked obstruction at the pylorus, $\mathfrak{a}$ superior enterostomy is a good substitute for gastroenterostony, the idea being to short circuit the stomach. In patients with serious lesions of the stomach the clanees for betterment are increased if no food passes through this organ at all. In one patient, a woman on whom superior enterostomy was performed, a dingnosis of carcinoma was made. The patient was very nuels cmaciated; there was pyloric obstruction and there was no free hydrochloric acid. I thought that I could feel the thick. ened pylorus and when the tube was passed, obstruction was also found at the cardiac end. The surgeon who was called in wanted to do gastroenterostomy, but it was decided that a superior enterostomy was to be preferred. On exposing the stomach there was found a small tumor at the pylorus. A section was not nuade, but taking it for granted that the tumor was a cancer, enterostomy was performed, and the palient was nourished through the fistula in the small intestines. I wish to emphasize that the diet should be watched with care. In the course of three or four weeks the symptoms in this putient were somewhat relieved; however, she had so much mental distress because of the fistula that we decided to close it, believing that she would die soon anylow. Th..t was in 1898. To our surprise, the woman made a good recovery and has remained well ever since. The tumor could not have been a cancer; just what it was I do not know.

Dik. Gustav Baar, Portland, Ore.: It seems to me that at mortality of $20 \mathrm{per}$ cent. is too high in such cases. I lave had sixteen patients operated on by surgeons during the last few years, and none died. Two of these cases were most remarkable. One patient was a woman of sixty, six feet tall, with a palpable tumor and with frequent hemorrhages; she was much emaciated, weighing but ninety-eiglut pounds. A gastroenterostomy was performed, and the surgeon thouglit that he was dealing with a carcinoma. I insisted, however, on the diagnosis of an indurated ulcer. There was free hydrochlorio acid present. The patient took nourishment without the ollghtest distress, being given lamb cliops on the third day ufter operation. At the end of two months her weight had increased to 168 pounds. This was only two years ago; 
the patient, at this date, is perfectly well. In another case the tumor was the size of the fist and appeared in a man aged forty-five. He had repeated hemorrhages. A diagnosis of indurited ulcer was made and a gastroenterostomy was performed. The man was absolutely cured. I believe that gastroenterostomy gives the most satisfactory results in all casts of prloric ulcer and is a real boon to suffering humanity.

Dh. Johx D. Dexus , Columbus, Ohio: In regard to the symptomatic cure of these patients $J$ wish to emplasize the fact that such patients slould be followed for a number of years before any final conclusions regarding them should be considered. The surgeon who sees these cases finds the patients sufticicutly recovered to leave the hospital and he cites such cases as recoveries. However, the general practitioner who follows the cases will often find recurrences. In the serios of case's reported there was only one in which a secondary operation was called for. If the caties are properly selected and only those patients with stenosis are operated on, a secondary operation will rarely be needed. Attention to the dict is very important. These patients with partial or complete pyloric stenosis are starved, as a rule, and they require abun. dant feeding; they cannot live on slops; the choicest and best food proper!y prepared should be given them for many weeks. The foud should be given frequently through the day and not as is customary, three times a day. In a consideration of the mortality the surgeon includes only the deaths which oceur immediately after the operation, while the general practitioner and the internist follow the patient's history for several years. The mortality after gastroenterostomy should only be considered when' the cases have been studied for five or six yenrs. In the series I reported there were two cases in which perforation of the stomach occurred and two in. which carcinoma developed.

\section{BLOODLETTING IN CHILDREN *}

\section{HEINRICH STERN, M.D. NEW YORK}

\section{FIS'IORY OF JBLOODLIEITING}

'The history of bloodletting prior to the nineteenth century gives but scant mention of the employment of this therapentic measure in children. The very fact, however, that ancient and medieval medicine would under ordinary circumstances not dispense with depletion justifies us in assuming that the children were subjected to the same procedure, although little special reference to this custom can be found. In Stöffler's "Calendarium romanum magnum" (1518) and in the "Medicina magica" (1568) it is stated that astrology, which influenced and pervaded the entire theory and practice of medicine of the times, accepted the theory that, according to situation and conjunction of the heavenly bodies, there existed favorable, dubious and unfavorable depletion days; the various periods of life had different days on which bloodletting was to be preferentiflly performed.

'The phase between half' and full moon was deemed especially to favor depletion of young persons, but to be inimieal to the operation in old people. In nurslings blood was probably never abstracted for therapentic purposes in the olden times.

'The literature of the first half of the nineteenth century contains not infrequent allusions to bloodletting in shildren. On the whole, the opinions of the foremost clinicians of that period were opposed to it. According to a very brief historical sketch pertaining to this epoch

- Read in the Section on Diseases of Children of the American Medleal Association, at the Sixty-first Annual Session, Leld at $\mathrm{St}$ Louls, June, 1010 and lurnished by Baginsky, Bretonneau as well as Louis (1835) Jepudiated depletion in the treatinent of diphtheria; the latter also renounced bloodletting in pneumonia and erysipelas. Bailly and Legendre afterward declared against the procedure in bronchopneumonia (catarrhal pneumonia), but recognized its value in lobar jnenmonia (fibrinons pneumomia). Among the Germans, Walther (1835), Wetzlar (1837) and Nasse (1849) expressed their opposition to blood abstraction in children. 'The pedintrist, Manthner, of Vienna, on the other hand, was an energetic adrocate of general and local depletion in children, especially in pneumonia and other febrile affections.

In a masterly discourse on the " $\Lambda$ ntiphlogistic Treatment in Discases of Children," which is spread over five issues of the Medical Record of $1870^{2}$ Jacobi also deals with the problem of bloodletting, and asks the question, "Are we justified in resorting to depletion at all?" Ho says:

It is an established fact, or at least a very general con. viction, that when we perform venesection-for the relief of pneumonia or meningitis, for example-we do not relieve tha pneumonia or the meningitis itself, but we do relieve the collateral chema which has taken place in the tissues as yot uninvaded, or but partially invaded, by the inflammation. And by this relief of the collateral congestion and edemn of the meninges or of the brain, we may save a patient from ap proaching dissolution. Such cases are rare; but when they oceur, when we have to deal witl neute edema, we must of course resort to depletion in many a case. I recall a case of convulsions in which I myself opened the jugular vein. I did not know the canse of the convulsion, but the venous congestion was so evident and so extreme, that $I$ was led to relieve it sts soon as possible. I think Troussenu relates a similar case. We know that the inmediate danger in such cases depends not on the primary cause of the affection, but on the prolonged congestion, which may give rise to effusion or extravasation. To avert these I do not object to venesectionindeed, it may become imperative. . . But to depletion as a general antiphlogistic I must object, and this whether it be made by venesection or by locul bloodletting. . . We often lear of plethora, of surplus of blood; if such a condition ever occurs, it is certainly not in infancy. At that period any surplus would be sure to be used to build up the body, to contribute to growth.

Accordingly, Jacobi seldom resorted to depletion in inflammatory diseases of infancy and childhood, and, although meningeal and cerebral affections sometimes recpuired direct depletion, he believes that generally, "wherever extensive derivation is really indicated," stimulation of the emunctories will be more effective than a local withdrawal of blood about the head.

The literature from $18 \% 0$ to 1890 contains very little anent the subject of depletion in the young. Jewett, ${ }^{3}$ in 1891, recommended moderate bleeding for young girls of full habit who suffer from menstrual irregularities, dysmenorrhea or temporary suspension of the flow, accompanied by flushed face, headache and a throbbing pulse. Lisner, ${ }^{4}$ in 1897, published the following interesting case:

A boy, 8 years old, well developed, was affected with a mild form of scarlatina. The disease had about abated when $n$ grave nephritis supervened. 'The cyelids were edematous; the urine contained about 1 per cent. albumin and showed, micro.

1. Bnginsky, A.: Velel allgemelne irtllebe Blutentzieliungen in der Kinderhellkunde, Berl. klin. Wchnscbr., 1808, p. 457: Ueber die Indicationen und Contraindleationen des Aderlasses bel Kंindern. Areh. f. Kinderl., 1901, xxxi, 350.

2. Jacobi, A.: Med. Rec., New York, $1870, v, 245$

3. Jewett, Homer C.: North Carolina Med. Jour., June, 1841.

4. Lissner: Beitrag zur Anwendung des Aderlasses bel Urilule. Aerztliche Plakt., 1897 , No. 6 . 